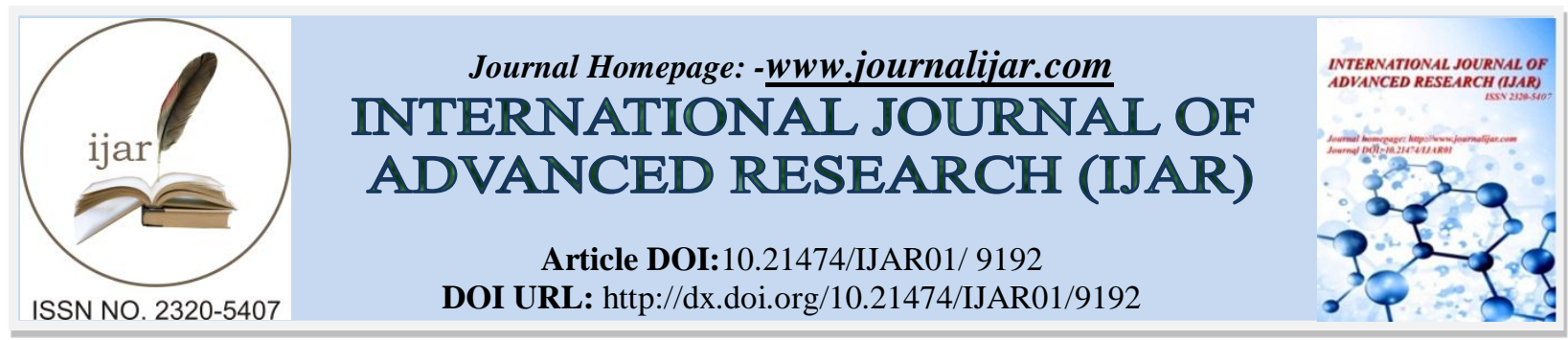

RESEARCH ARTICLE

\title{
PSYCHOLOGY FACTORS IN PROCESS AND LEARNING OUTCOMES.
}

Sokip.

Associated Professor of State Islamic Institute of Tulungagung, East Java, Indonesia.

\section{Manuscript Info}

\section{Manuscript History}

Received: 02 April 2019

Final Accepted: 04 May 2019

Published: June 2019

Key words:-

Learning process, Learning Outcomes,

Psychology Factor.

\begin{abstract}
Learning is a process of deepening an ability that has the goal of achieving individual insight. The elements built are pre-learning, process, and learning outcomes which are done in classroom as usual. However, sometimes learning becomes so lack because low participation and motivation on learners then automatically can effect on his learning achievement (outcomes). Hard effort to provide teaching strategies and material academically already served by teachers but still found some learners who have low motivation to learn. Hence in this paper wants to investigate what are the else factors regarding with this case. The way to answer the research question, researcher uses analyzing inductive and deductively, or shortly called as library research. Result showed that another factors are actually found as psychology factor. It refers to learners' personality and capability to participate and catch the material given by the teacher. At least there are four important points found here, among others; intelligence factor, motivation factor, interest factor, and cognitive factor. Those must be paid attention for each teacher not only serving well academic classroom element.
\end{abstract}

Copy Right, IJAR, 2019,. All rights reserved.

\section{Introduction:-}

Nowadays, the position of education more advanced because the influence of modern technology. In this case, many people especially teacher and students who use the advantages of technologies provided for their efficient work and learning. Many media provided variety of information that makes every user can reach it easily even efficiently rather than searching information by offline. Education has been witnessing a rapid acceleration of changes in information and communication technologies (ICT) in the past few years. Education should be reachable and inclusive (Senthamarai and Khanaa, 2013). Moreover, this century also emphasize students in mastering any skills to follow development era, if otherwise they will be considered as out of date somebody to live fully in developed era. In line with previous statements, Nirwana et al., states that the global demand of $21^{\text {st }}$-century students is that students have to master the various skills in their learning process. These skills refer to the four life principles that include learning to know, learning to do, learning to be and learning to live together (Nirwanaet al, 2018). Regarding with term of learning, in general it is a process in making better life for human by doing some efforts. According to Sokipet al (2019) learning in general is a process of humanizing people from those who do not know something to know even later able to create a new change in human life. Learning is a process, an activity, and not a result or a goal. Learning is not just remembering, but more broadly than that, that is experiencing.

Corresponding Author:-Sokip.

Address:-Associate Professor of State Islamic Institute of Tulungagung, East Java, Indonesia. 
By understanding the current education case, as teacher must be aware on what is going on students' condition and needs. Learning nowadays does not stuck in degree of media used or even material presented in the classroom, but it also considers to students characteristic which is so various. Sometime, as teacher has tried hard to prepare the material and teaching media but the outcome becomes otherwise or far from the expectation. The students are still lack in understanding the material, bored with the teacher's performance and still many others.

Actually most of the subjects taught in school use teaching method to help students easily comprehend the material served by teacher. In secondary schools, there are actually various supporting facilities for learning itself. Usually, there is a kind of language laboratory room to the point of adequate electronic media. Again and again, there are still a large number of students who have difficulty in receiving material from their teachers.

The fact shows that most students are lazy faster and lose concentration when taught by their teacher. The position of a teacher is totally in guiding students to understand the material. In addition, there are still many small portions which usually do not even enter or in quotes "skip". The students assumed that the lessons were less interesting and sometimes they told the teacher directly. Judging from these problems the possibility of child psychological factors or child psychology can be considered as a trigger for the problems being faced in the Arabic class. Actually the effect of teaching methods on students' learning should be the interest of every teacher and student (Alam, 2018). If still many students are lack in participating within learning process then must there another factors indicated to students' condition themselves, briefly it is quoted as psychology of students.

Hence, this study focuses on finding what are indicated factors influenced students learning process by looking for some relevant literature. The aim of this study is to find out what are the factors related with students circumstance in receiving lesson at school.

Literally, Learning is a process of deepening an ability that has the goal of achieving individual insight. Moreover, learning is a process of adjustment through stimulation and accommodation between the basic tools of cognitive stimulation with individuals (Budiman, 2017). Learning is actually a variety of forms in terms of location. This is caused, that wherever someone can search and add knowledge by learning and with anyone can carry out the learning process. Nevertheless, the process of acquiring knowledge is not easy and needs to be considered many things so that individuals really understand the knowledge being studied. Winkel (1987) adds that learning is a mental or psychological activity, which takes place in active interactions with the environment, which results in changes in knowledge-understanding, skills and attitudes. Changes are of a relative nature and trace. Bhatia defines learning as a relatively permanent change in knowledge, behavior and understanding, as a result of experience (Bhatia, 2009).

Learning outcomes meant in soul of students literally can be found by two triggers. In this case, the factor (trigger) stimulates students to be good or bad in facing learning process. Learning outcomes of students is being influenced by two factors such as internal and external factor. Internal factor can be in form of health problems, disability, psychology factor (intelligence, learning interest, attention, talent, motivation, maturity and readiness of students), and exhausted factor. While, external factor which influence the learning process and outcomes of student consist of family, school, community factors (Nurhasanah and Sobandi, 2016).

The learning process and psychology is a unit that cannot be separated. A teacher must be good at choosing teaching materials and strategies but also must pay attention to the psychological conditions of his students. According to Crow and Crow, Psychology defines as behavioral learning and human relations (Djamarah, 2011). The essence of this paper itself is a discussion of the relationship of psychology and school learning which is felt to have a relationship and relevance to the factors of ups and downs of students' achievement in the Arabic class. In other words, when combined Psychology of learning is psychological theories about learning, especially discussing how individuals learn and do learning. Even the topics in learning psychology include (1) learning theories; (2) learning principles; (3) the nature of learning; (4) types of learning; (5) learning activities; (5) effective learning techniques; (6) characteristics of changes in student learning outcomes; (7) manifestations of learning behavior; (8) factors that influence learning (Djamarah, 2011).

\section{Methods:-}

This study uses library research design to solve the problem formulation. Library research is the method to get the data from related and relevant books based on the problem formulation (Hadi, 1981). This approach type in name of 
library research is contained a topic that load several arguments and or information from literature as the source. The materials of literature used must be discussed critically and deeply to support the argument or proposition to produce conclusion and advice. Data source is a source that is used or information which consist of whole discussion from the problem formulation. Moreover, the data gets from relevant psychology books, scientific journals, and other else literatures. The way to analyze the gathered data, the writer uses qualitative analysis that is done by through inductive analysis and deductive analysis. Inductive analysis is the way of thinking in getting the conclusion that is started from statement or specific facts into general conclusion. In line with Hadi (1981) that states inductive analysis is making conclusion which started from specific definition becomes general definition. Deductive analysis defines as the way of thinking to get the conclusion started from general statement into specific questions by using logical reason. According to Hadi (1981) states that if someone can prove that certain event includes the right view, it means logically and automatically he can make the conclusion that the truth in the problem becomes the truth of specific event.

\section{Result and Discussion:-}

After conducting deeply research about factors related with students enthusiastic in Arabic class, then researcher found some new findings. Actually, the problem is not totally stuck in teaching strategy applied by teacher, meanwhile toward students condition themselves. Factors that affect learning are actually very diverse can be seen in terms of infrastructure that affects from the outside and psychological conditions of students themselves which indirectly becomes a factor from within if the facilities and teaching strategy are taken place nicely. Then, the indicator of psychology factors must be involved in this case too and become another factors to be found and discussed. Actually, there are some terms indicated to students' performance toward the lesson. According to Djamarah (2011) in his book "Psychology of Learning" factors from outside include the Environment and Instrumental while from the inside are the physiological and psychological conditions of students. Psychologically there are a number of important points that influence the process and learning outcomes, including (1) intelligence; (2) motivation; (3) interest; (4) cognitive skill and still many others. In this opportunity, the writer gives limitation in form of four psychology factors in learning.

\section{IntelligenceFactor}

It is the innate ability of each individual. In fact, every student has variety of intelligence which can be seen from their learning style and hobby. Most of them refer to visual, audio, or even kinesthetic. Intelligence is a general term used to describe the nature of mind which includes a number of abilities, such as reasoning, planning, problem solving, abstract thinking, understanding ideas, using language, and learning. Intelligence is closely related to cognitive abilities possessed by individuals (Mujib and Mudzakir, 2002). Intelligence is about intelligence, the perfection of human reason. The word intelligence is taken from the root of intelligent words. In case of education, this belongs to be one of some factors for students' learning style later. According to Djamarah concludes that intelligence is one of many factors that influences individual success in learning at school (Djamarah, 2011). On another hand, According to Daniel Goleman (2004), intelligence refers to IQ or Intelligent Quotient only gives $20 \%$ for success, while 80\% refers to further factors such as EQ or Emotional Quotient (ability to motivate own self), facing frustrated condition, control desire, manage mood circumtances, empathy, also ability of team work. Then, it can be said that Intelligence is significantly influence students learning however not as the only reason why a student face difficulties while learning is taking place in the classroom.

\section{Motivation Factor}

The position of motivation is quietly important in each circumstance either education or another else program. By having this point, an individual can be more confident to pass any kinds of condition and problem forward. This due to motivation defines as energy to raise certain behavior and attitude of people. If students have good motivation means they do not feel down in any different condition faced by them. According to Ormrod defines motivation as something inside of human to energize, guide, and defend the behavior (Latipah, 2012). When analyze deeply, this factor of learning can be defined into two types based on its input, either from inside of individual or affection from his environment outside. Moreover, if the input of motivation is good obtained by students then they will be more creative to produce something in classroom and vice versa. Creativity is based on intrinsic and extrinsic motivation in addition to personal traits (Khalil et al, 2017). Extrinsic motivation sourced from teachers, environment of class, friends, family support and many others. While intrinsic motivation is sourced from individual without any trigger from people or environment such as personality, attitude, own experience, aims and still many others. By knowing that, then it can be concluded if a student has lack in learning means he probably has low motivation to follow classroom activities. Suggestion from Djamarah if students are low in motivation then they need encouragement 
from beyond, in this case refers to Extrinsic motivation, so that they are motivated to learn again, one of the way is that teacher should give reward either orally or written in classroom activity as always.

\section{Interest Factor}

Interest defines as a feeling more on what being liked and has its own attractive on something. Every one actually has different interest on certain activities or cases, for instance a students who prefers Math than Arabic as subject in the classroom. This can't be denied and can't be asked why people has tendency. Basically, the interest has considered as reception on certain relationship between individual with something or someone beyond (Djamarah, 2011). It means the closer and stronger the relationship, the greater the interest will become. In fact, the correlation between interest and learning outcome can be seen from how enthusiast a student give massive attention on interested subject they like. If these become to be greater then automatically the achievement will increase too. Meanwhile, if the interest of subject is less or even lack then the learning outcome will be decrease or low. Hence, interest factor must be paid attention by all teachers somehow a teacher is the main role to help a student's interest to subject teacher taught. Djamarah adds in terms on how to activate student interest on subject taught is by involving student's previous interest into material taught. For instance, students basically like drawing, then drawing must be included in teaching strategy of Arabic subject. In fact, the students mentioned an interest in "learning about building", understanding how things go together", making things, or gaining real life (real world) experience in place of just designing (Canizaro, 2012). Learning interest actually can be measured through 4 indicators among others; the attraction in learning, attention in learning, motivation in learning, and knowledge (Nurhasanah and Sobandi, 2016).

\section{Cognitive skill Factor}

This skill must be had by all students and the prior tool in obtaining such information becomes certain knowledge from all input or sources. Briefly, this tool is related to how people think and get knowledge by their brains. According to Djamarah (2011) this skill must be mastered by each student because this skill becomes a basis of knowledge mastery. There are three skills that must be mastered to get cognitive skill among others; perspective or view, memorizing, and thinking. Even, in term of education this skill becomes one of indicator the success of learning process. One important goal of design education is to develop students' independent abilities of designing and to enhance their cognitive and representation skills (Tezel and Casakin, 2010). Different capacity and capability of memorizing on student can influence the way to get knowledge at school. This factor is important enough used in classroom activity especially toward memorizing activity, if the level of memorizing and thinking are high then automatically students can easily enhance achievement at school.

\section{Conclusion:-}

The learning process and psychology is unit that cannot be separated. Hence, learning outcomes which done by students either good or low achievement depends on certain related factors felt by students during learning process. In fact, it is not only stuck on academic factor, this study showed the psychology factor has a role in building learning outcomes. Based on finding, there are four found factors influenced by learning process and outcome. They are intelligent factor, motivation factor, interest factor, and cognitive skill factor which those are considered as psychology element of human life. Moreover, teacher is suggested to be aware on what students experienced while learning process and not only stuck talking about the outcome which done by students. Hence, the ability in improving students' intelligent, interest, motivation, and cognitive skill should be had by each teacher. 


\section{Reference:-}

1. Alam, QaziNaeem. (2018). A Comparative Study between Focused and non-Focused groups of students to enhance their examination's performance ISSN Print 2394-7500, ISSN Online 2394-5869 (135-140). India: IJAR-International Journal of Applied Research

2. Bhatia, M.S. (2009). Dictionary of Psychology and Allied Sciences.New Delhi: New Age International

3. Budiman, Asep. (2017). Behaviorism in Foreign Language Teaching MethodologyVol 1 No 2.STAIN Curup: English Franca

4. Canizaro, Vincent B., (2012). Design-Build in Architectural Education: Motivations, Practices, Challenges, Success and Failures Vol. 6 issue 3 (20-36). Archnet-IJAR International Journal of Architectural Research

5. Daniel Goleman. (2004). Emotional Intelligence (translated) Kecerdasan Emosional Mengapa EQ Lebih Penting Daripada IQ. Jakata: PT Gramedia Pustaka Utama

6. Djamarah, SyaifulBahri. (2011). PsikologiBelajaredisirevisi.Jakarta: PT RinekaCipta

7. Khalil,. Mohamed, Elsaay, Heba, Othman,. Anyman. (2017). Talent Management: A Novel Approach for Developing Innovative Solutions toward Heritage Communities Development Vol. 11 Issue 3 (132-145). Archnet-IJAR International Journal of Architectural Research

8. Latipah, Eva.(2012).Pengantar Psikologi Pendidikan.Yogyakarta: PT. Pustaka Insan Madani

9. Mujib, Abdul dan Mudzakir, Jusuf.(2002). Nuansa-Nuansa Psikologi Islam.Jakarta:PT.Raja Grafindo Persada

10. Nirwana F. Bayu, SuyatnaAgus and Ertikanto Chandra. (2018).Development of Learning Strategy Based Inquiry to Build Student Argumentation Skills. International Journal of Advanced Research), ISSN: 2320-5407. DOI:10.21474/IJAR01/7079. India: IJAR-International Journal of Advanced Research

11. Nurhasanah, Siti and Sobandi, A. (2016). Minat Belajar sebagai Determinan Hasil Belajar SiswaVol 1 No 1 (135-142). Bandung: Jurnal Pendidikan Manajemen Perkantoran

12. Senthamarai, R. and Khanaa, V. (2013). Intelligence in E-Learning for Differently Abled (A Literature Survey) Vol. 1 Issue 10 ISSN 2320-5407 (518-523). India: IJAR-International Journal of Advanced Research

13. Sokip, Akhyak, Kozin, and Soim. (2019). The Implementation of Behavioristic Learning Theory in Senior High School DOI:10.21474/IJAR01/8557. IJAR (International Journal of Advanced Research)

14. Tezel, Elcin and Casakin, Hernan. (2010). Learning Style and Students' performance in design problem solving Vol. 4 Issue 2-3 (262-277). Archnet IJAR-International Journal of Architectural Research

15. Winkel, W.S. (1987). PsikologiPengajaran. Jakarta: PT Gramedia. 